\title{
Implementasi Fungsi Hash MD5 dan Kriptografi Algoritma RSA Pada Pembuatan Tanda Tangan Digital
}

\author{
Annisa Hardiningsih HR ${ }^{1}$, Muhammad Khudzaifah ${ }^{2 *}$, M. Nafie Jauhari ${ }^{3}$ \\ 1,2,3Program Studi Matematika, Fakultas Sains dan Teknologi, Universitas Islam Negeri Maulana Malik \\ Ibrahim Malang, Indonesia
}

Email:xxnisaaaa@gmail.com, khudzaifah@uin-malang.ac.id*,nafie.jauhari@uin-malang.ac.id

\begin{abstract}
ABSTRAK
Penggunaan dokumen elektronik mengalami peningkatan karena kebijakan Work from Home (WFH) yang dikeluarkan oleh pemerintah Indonesia. Namun penggunaan dokumen elektronik masih memiliki kelemahan dalam hal keautentikannya. Salah satu cara untuk mengatasinya adalah dengan menerapkan tanda tangan digital. Penelitian ini membahas penerapan tanda tangan digital dengan menggabungkan dua algoritma, yaitu fungsi hash MD5 dan kriptografi algoritma RSA pada tiga puluh dokumen elektronik berformat Portable Document Format (PDF). Tanda tangan digital dibuat dengan memberikan fungsi hash MD5 pada isi dokumen, sehingga menghasilkan message digest. Selanjutnya message digest dienkripsi menggunakan algoritma RSA. Tanda tangan digital diverifikasi dengan memberikan fungsi hash MD5 pada isi dokumen elektronik dan mendekripsi tanda tangan digital dokumen elektronik. Hasil pengujian menunjukkan tanda tangan digital yang dihasilkan adalah berbeda-beda dari setiap dokumen elektronik. Dokumen elektronik yang menghasilkan nilai dekripsi tanda tangan digital dan message digest modulo $n$ yang sama pada saat verifikasi menunjukkan bahwa dokumen elektronik tidak mengalami perubahan pada isinya. Sebaliknya, dokumen elektronik yang tidak menghasilkan nilai dekripsi dan tanda tangan digital dan message digest modulo $n$ yang sama pada saat verifikasi menunjukkan bahwa dokumen elektronik telah mengalami perubahan pada isinya. Penelitian ini diharapkan dapat menjadi salah satu upaya dalam meminimalkan risiko pemalsuan dokumen elektronik.
\end{abstract}

Kata kunci: Dokumen elektronik; MD5; RSA; tanda tangan digital

\begin{abstract}
The use of electronic document has increased due to the Work from Home (WFH) policy issued by Indonesian government. However, the use of electronic document still has weaknesses in terms of its authenticity. One way to overcome this is using digital signature. This study discusses the application of digital signature using two algorithms, namely MD5 hash function and RSA algorithm cryptography on thirty electronic documents in Portable Document Format (PDF). The digital signature is created by assigning an MD5 hash function to the document's content, so it obtains the message digest. Then, the message digest is encrypted using the RSA algorithm. The digital signature is verified by assigning an MD5 hash function to electronic document's content and decrypting electronic document's digital signature. The results show that the digital signatures produced are different from each electronic document. Electronic document that
\end{abstract}


produces the same decryption and message digest modulo $n$ values indicate that the electronic document has not changed its content. On the other hand, electronic documents that do not produce the same decryption and message digest modulo $n$ values indicate that electronic document has changed in its content. This study is expected to be one of the efforts to minimize the risk of falsification of electronic document.

Keywords: digital signature; electronic document; MD5; RSA

\section{PENDAHULUAN}

Pandemi COVID-19 di Indonesia membuat pemerintah mengeluarkan kebijakankebijakan baru. Salah satunya yaitu kebijakan Work from Home (WFH). WFH merupakan suatu konsep di mana para pekerja dapat bekerja secara fleksibel dari rumah karyawan tersebut secara online [1]. Kebijakan WFH ini mengakibatkan beralihnya sistem manual ke sistem digital [2], salah satunya yaitu penggunaan dokumen. Dokumen yang sebelumnya berbentuk print-out, sekarang berbentuk dokumen elektronik.

Dokumen elektronik merupakan dokumen berbentuk analog, digital, atau sejenisnya yang dibuat, diteruskan, dikirimkan, diterima atau disimpan. Dokumen elektronik dalam penggunaannya memiliki kekurangan dalam hal keotentikannya. Hal ini karena dokumen elektronik sangat mudah untuk diedit [3]. Oleh karena itu dibutuhkan suatu mekanisme guna menjaga keotentikan dokumen elektronik, yaitu tanda tangan digital.

Penelitian sebelumnya mengenai tanda tangan digital pada "Authentication System for E-Certificate by Using RSA's Digital Signature" [4] menunjukkan bahwa proses penandatanganan dan pengecekan diselesaikan dengan cepat ketika aplikasi penandatanganan diterapkan dengan Chinese Remainder Theorem (CRT). Selanjutnya pada "Data Integrity and Security using Keccak and Digital Signature Algorithm (DSA)" [5] menunjukkan bahwa algoritma Keccak dapat diterapkan pada sistem DSA, serta diperoleh perbandingan waktu eksekusi proses signing dan verifying antara DSA dan RSA ketika menggunakan algoritma Keccak.

Penelitian ini bertujuan untuk mengetahui hasil tanda tangan digital dan verifikasinya pada dokumen elektronik berformat PDF menggunakan fungsi hash MD5 dan kriptografi algoritma RSA. Penelitian ini diharapkan dapat menjadi salah satu upaya dalam meminimalkan risiko pemalsuan dokumen elektronik, khususnya yang berformat PDF.

\section{Tanda Tangan Digital}

Tanda tangan digital memiliki kemiripan dalam aspek kegunaannya, yaitu menjamin keaslian dan persetujuan dokumen oleh penandatanganan. Namun tanda tangan digital bukanlah tanda tangan yang di-digitalisasi oleh alat scanner atau tanda tangan yang dibuat dengan pena elektronik [6]. Tanda tangan digital merupakan suatu nilai kriptografi yang memiliki ketergantungan pada isi pesan dan pengirim pesan [7]. Oleh karena itu, tanda tangan digital dari pesan yang berbeda, walaupun dengan pengirim yang sama, akan memiliki tanda tangan digital yang berbeda [8].

Dalam menjaga validitas data, pengirim diharuskan menandatangani dahulu dokumen yang hendak dikirim. Kemudian penerima dapat memeriksa tanda tangan pada dokumen untuk memastikan bahwa dokumen yang diterima masih asli. Segala aktivitas yang dilakukan oleh pengirim disebut signing dan aktivitas yang dilakukan oleh penerima disebut verifying [9]. Tanda tangan digital menggunakan algoritma hashing akan 
membentuk sebuah kombinasi karakter yang khas disebut message digest [10] dan message digest ini akan dienkripsi menggunakan algoritma kunci pribadi. Hasil enkripsi dari message digest inilah yang disebut sebagai tanda tangan digital dari suatu dokumen. Dengan cara ini pengirim bertanggungjawab terhadap isi dokumen dan penerima dapat mengecek keaslian dokumen [11].

Tanda tangan digital dapat dilakukan dengan salah satu dari dua cara, salah satunya yaitu tanda tangan digital dengan penggabungan algoritma hashing dan algoritma kunci publik [12]. Tanda tangan digital pada penelitian ini dibuat dengan menggunakan kombinasi algoritma hashing, yaitu MD5 dan kriptografi algoritma kunci publik, yaitu RSA. Berikut merupakan skema tanda tangan digital menggunakan algoritma hashing dan kriptografi algoritma kunci publik

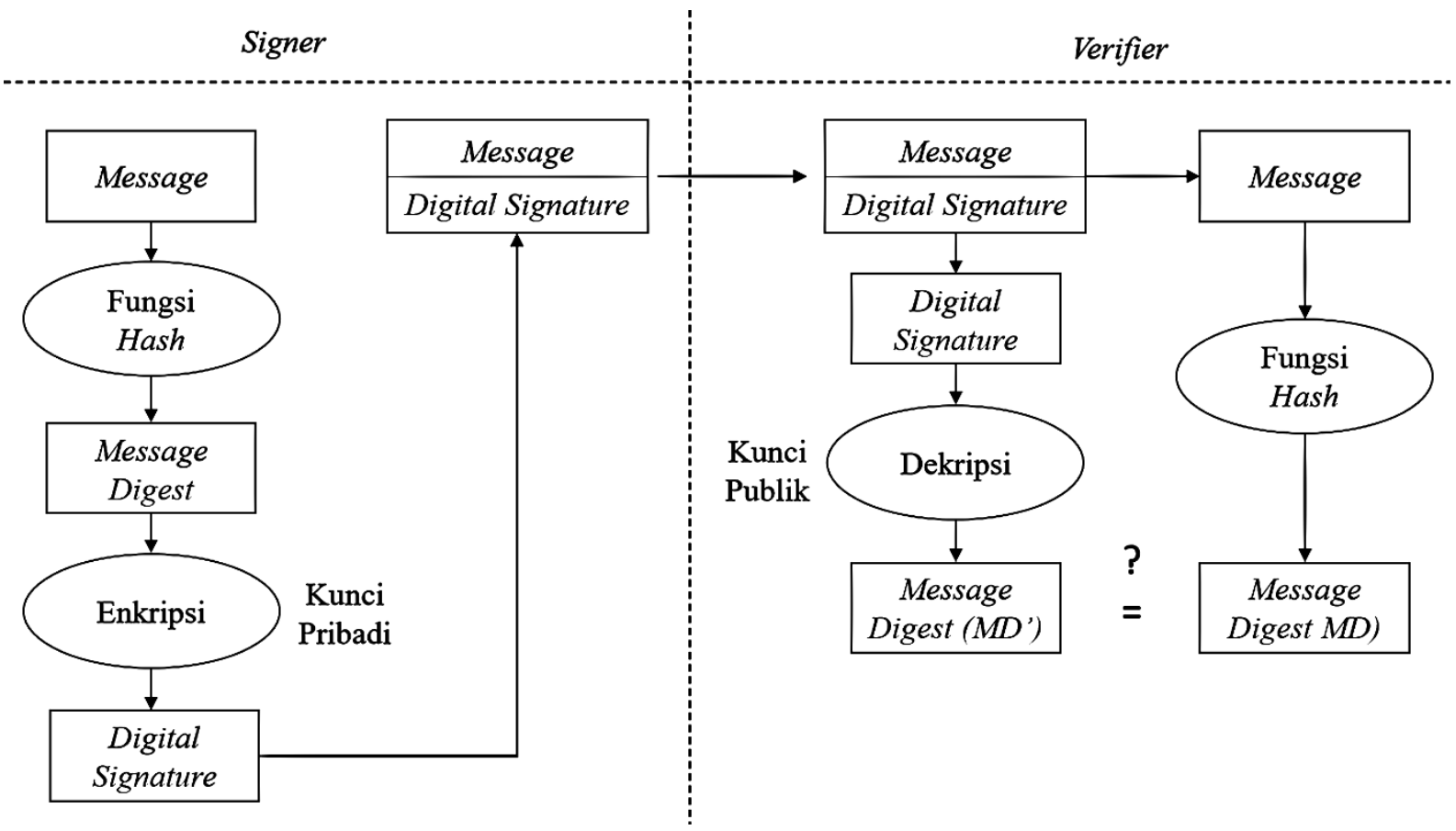

Gambar 1. Skema Tanda Tangan Digital

Berdasarkan Gambar di atas, proses penandatanganan yang dilakukan oleh pengirim (signer) adalah sebagai berikut:

1. Pengirim pesan menghitung nilai message digest pesan awal menggunakan fungsi hash.

2. Message digest dienkripsi menggunakan kunci pribadi pengirim pesan. Hasil enkripsi ini merupakan tanda tangan digital $S$.

3. Hasil tanda tangan digital dilekatkan ke pesan awal, lalu keduanya dikirim kepada penerima.

Proses verifikasi tanda tangan yang dilakukan oleh penerima (verifier) adalah sebagai berikut:

1. Penerima menghitung message digest pesan awal menggunakan fungsi hash.

2. Tanda tangan digital $S$ didekripsi menggunakan kunci publik pengirim pesan sehingga menghasilkan message digest.

3. Lihat apakah hasil dekripsi message digest dan message digest pesan awal bernilai sama atau tidak. Jika bernilai sama, maka tanda tangan yang diterima adalah otentik dan isi pesan tidak mengalami perubahan walau satu karakter. 


\section{MD5}

MD5 merupakan fungsi hash yang dibuat oleh Ronal Rivest pada tahun 1991. Pada MD5, pesan masukan berukuran sembarang dan message digest yang dihasilkan memiliki panjang 128-bit atau 32 karakter heksadesimal [13]. Message digest diperoleh dengan membahkan padding bits, menambahkan nilai panjang pesan semula, menginisialisasi buffer MD, dan mengolah pesan dalam blok berukuran 512 bit, di mana pengolahan ini terdiri dari empat buah putaran yang setiap putarannya terdapat 16 kali operasi dasar MD5 [12].

\section{RSA}

Pada tahun 1977, Ron Rivest, Adi Shamir, dan Leonard Adleman membuat algoritma RSA. Algoritma RSA merupakan algoritma kunci publik yang dalam proses pengerjaannya membutuhkan konsep matematika, yaitu Faktor Persekutuan Terbesar (FPB), algoritma Euclid, relatif prima, bilangan prima, aritmetika modular, dan kekongruenan. Keamanan algoritma RSA dilihat dari susahnya memfaktorkan bilanganbilangan prima besar dari proses pembangkitan sepasang kunci [14]. Hasil dari algoritma ini adalah kunci publik $(e, n)$ yang digunakan untuk enkripsi dan kunci pribadi $(d, n)$ yang digunakan untuk dekripsi dengan $e, d$, dan $n$ merupakan bilangan bulat positif [15]. Kunci yang digunakan pada enkripsi dan dekripsi pada pesan biasa berbeda dengan kunci yang digunakan pada tanda tangan digital. Pada tanda tangan digital, kunci pribadi $(d, n)$ digunakan untuk mengenkripsikan pesan dan kunci publik $(e, n)$ digunakan untuk mendekripsi pesan.

\section{METODE}

Tahapan-tahapan penelitian dilakukan sebagai berikut:

1. Membuat tanda tangan digital menggunakan fungsi hash MD5 dan algoritma enkripsi kriptografi RSA dengan prosedur sebagai berikut:

a) Menginputkan pesan (teks) berformat PDF.

b) Mengubah pesan menjadi message digest dengan cara sebagai berikut:

i. Menambahkan padding bits pada pesan dengan menambahkan 1 dan sejumlah 0 sampai panjang pesan kongruen dengan 448 modulo 512 .

ii. Menambahkan 64-bit pada pesan yang telah diberi padding bits.

iii. Inisialisasi buffer MD, yaitu $\mathrm{A}=67452301, \mathrm{~B}=$ EFCADB89, $\mathrm{C}=$ 98BADCFE, dan D = 10325476.

iv. Pemecahan pesan menjadi $Y_{0}, Y_{1}, Y_{2}, \ldots, Y_{L-1}$ berukuran 512 bit.

v. Melakukan proses MD5 sebanyak empat buah putaran.

c) Mengenkripsi message digest dengan kriptografi algoritma RSA sebagai berikut:

i. Memilih bilangan prima $p$ dan $q$.

ii. Menghitung nilai $n=p q$.

iii. Menghitung nilai $\phi(n)=(p-1)(q-1)$

iv. Memilih kunci publik $e$, dimana $\operatorname{gcd}(e, \phi(n))=1$

v. Membangkitkan kunci pribadi dengan persamaan $e d \equiv 1(\bmod (\phi(n))$

vi. Mengubah message digest yang diperoleh ke dalam bentuk desimal.

vii. Mengenkripsi message digest dalam bentuk desimal menggunakan kunci pribadi $d$ dengan rumus $c=m^{d} \bmod n$. 
viii. Mengubah hasil enkripsi message digest yang berbentuk desimal ke dalam bentuk heksadesimal.

2. Memverifikasi tanda tangan digital dengan menggunakan fungsi hash MD5 dan algoritma dekripsi kriptografi RSA sebagai berikut:

a) Menghitung message digest dari pesan yang diperoleh dengan fungsi hash MD5 seperti pada langkah $1 \mathrm{~b}$ ).

b) Mengubah hasil message digest ke dalam bentuk desimal.

c) Mengubah hasil tanda tangan digital yang diperoleh ke dalam bentuk desimal.

d) Menginputkan kunci publik $e$.

e) Mendekripsi tanda tangan digital yang diperoleh dengan algoritma dekripsi dengan rumus $m=c^{e} \bmod n$.

f) Membandingkan hasil message digest dan dekripsi tanda tangan digital.

3. Membuat program menggunakan bahasa pemrograman Python.

4. Mengimplementasikan program pada tiga puluh dokumen elektronik yang digunakan.

\section{HASIL DAN PEMBAHASAN}

Proses penandatanganan dokumen elektronik menggunakan fungsi hash MD5 dan kriptografi algoritma RSA pada dokumen pertama menggunakan program yang telah dibuat dapat dilihat pada Gambar 2 berikut:

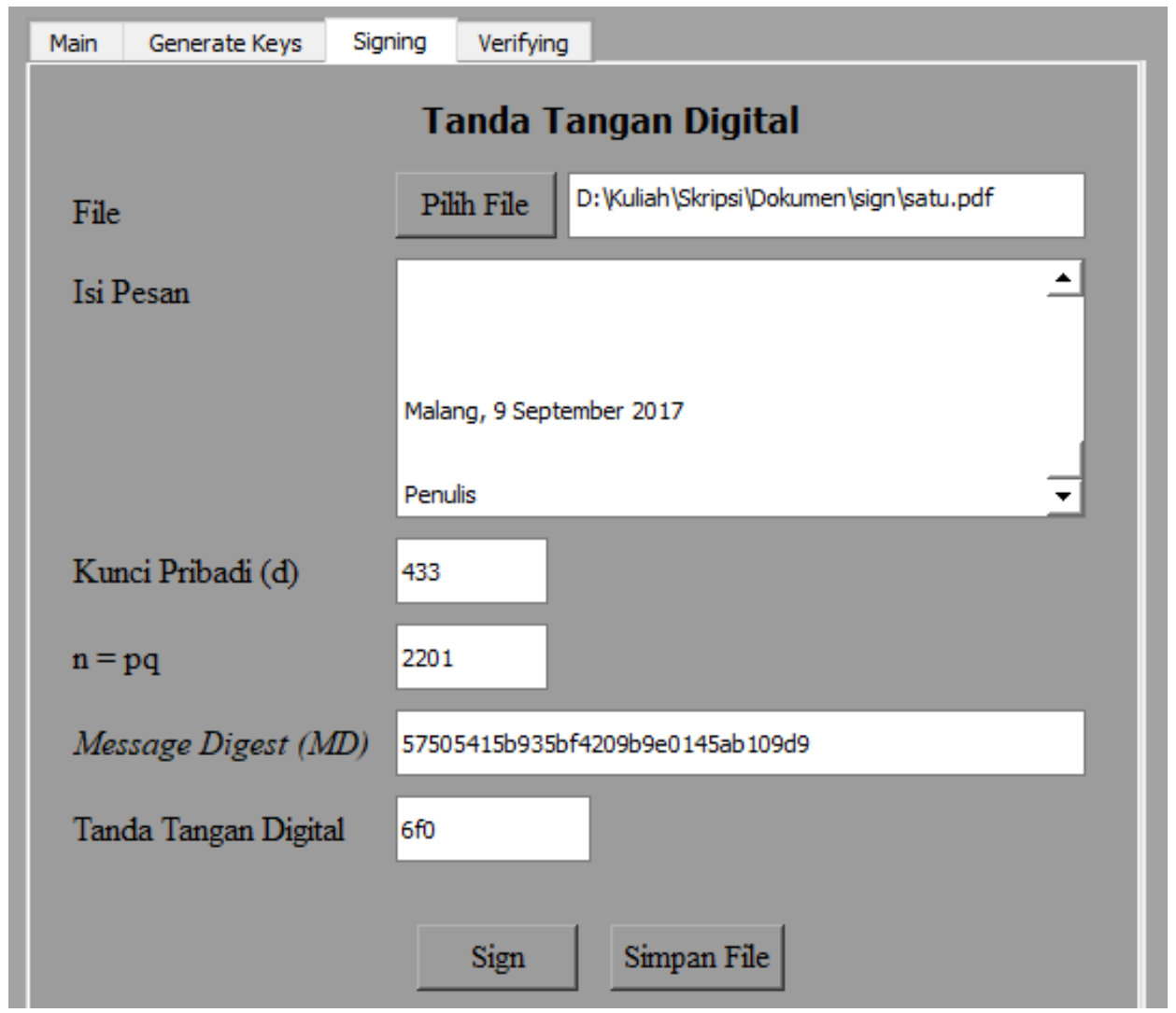

Gambar 2. Hasil Tanda Tangan Digital Dokumen Pertama

Berdasarkan Gambar 2, diperoleh message digest adalah

$57505415 b 935 b f 4209 b 920145 a b 109 d 9$

Selanjutnya message digest ini diubah ke dalam bentuk desimal, sehingga diperoleh 


\section{3}

Message digest dalam bentuk desimal ini akan dienkripsi menggunakan kunci pribadi. Kunci pribadi diperoleh dengan cara sebagai berikut:

1. Memilih nilai $p=31$ dan $q=71$.

2. Menghitung nilai $n$

$$
\begin{aligned}
n & =p q \\
& =31 \times 71 \\
& =2201
\end{aligned}
$$

3. Menghitung nilai $\phi(n)$ dengan persamaan

$$
\begin{aligned}
\phi(n) & =(p-1)(q-1) \\
& =30 \times 70 \\
& =2100
\end{aligned}
$$

4. Dipilih $e=97$, dimana $\operatorname{gcd}(e, \phi(n))=1$. Lalu menghitung $d$ dari persamaan

$$
\begin{aligned}
e d & \equiv 1 \bmod (\phi(n)) \\
d & \equiv \frac{1 \bmod (\phi(n))}{e} \\
& =\frac{1+\left(k^{2} \times 2100\right)}{97}
\end{aligned}
$$

dengan mencoba nilai-nilai $k=1,2,3, \ldots$, diperoleh nilai $d=433$. Maka diperoleh kunci pribadi untuk enkripsi message digest, yaitu $d=433$.

Message digest dienkripsi dengan

\begin{tabular}{|c|c|c|c|}
\hline $\begin{array}{c}\text { Nama } \\
\text { Dokumen }\end{array}$ & Message Digest & $\begin{array}{l}\text { Kunci Pribadi } \\
\qquad(d, n)\end{array}$ & $\begin{array}{c}\text { Tanda } \\
\text { Tangan } \\
\text { Digital }\end{array}$ \\
\hline Satu & $\begin{array}{c}\text { 57505415b935bf4209b9e0145ab109d } \\
9\end{array}$ & 433,2201 & $6 f 0$ \\
\hline Dua & $\begin{array}{c}3 a 02 a 5 a 773 c 9596470 a 91 b d 2277 d c 0 c \\
d\end{array}$ & 2275,2701 & $a 77$ \\
\hline Tiga & 2004c1f59373182df37b15132a3ed255 & 5777,9797 & $132 c$ \\
\hline Empat & 8148710b4171f2206b579c0b9c9ff0a2 & 123,1837 & 122 \\
\hline Lima & $9217013676 a e a c d 967 b f a 2 f 3 a 6917569$ & 361,3233 & $1 e c$ \\
\hline Enam & $\begin{array}{c}\text { aec44c5ba60336a61787da7e882d346 } \\
1\end{array}$ & 3037,6283 & af7 \\
\hline Tujuh & d2ca5b4f7b382d1a3ee0da973bc01c7b & 797, 3901 & $67 e$ \\
\hline Delapan & eecd6169923cfa4da41ad1c8172c68c4 & 117,391 & 20 \\
\hline
\end{tabular}

$c=m^{d} \bmod n$

$=116059924825488289768352942606727055833^{433} \bmod 2201$

$=1776$

Hasil enkripsi yang diperoleh adalah 1776 yang dalam bentuk heksadesimal adalah $6 f 0$. Maka tanda tangan digital dokumen pertama adalah $6 f 0$.

Hasil tanda tangan digital dari tiga puluh dokumen elektronik dapat dilihat pada Tabel berikut ini:

Tabel 1. Hasil Tanda Tangan Digital dari Tiga Puluh Dokumen Eletronik 


\begin{tabular}{|c|c|c|c|}
\hline $\begin{array}{c}\text { Nama } \\
\text { Dokumen }\end{array}$ & Message Digest & $\begin{array}{l}\text { Kunci Pribadi } \\
\qquad(d, n)\end{array}$ & $\begin{array}{c}\text { Tanda } \\
\text { Tangan } \\
\text { Digital }\end{array}$ \\
\hline Sembilan & faade28365e90f633b43e5ebb51aabe6 & 10909,13561 & $266 e$ \\
\hline Sepuluh & $\begin{array}{c}\text { 0b0b2f73869527a81903b8021e30d9d } \\
9\end{array}$ & 8251,11581 & aae \\
\hline Sebelas & c45b78ecc3e0cb8efd72e2b2af5f3ca6 & 3799,7807 & $31 e$ \\
\hline Duabelas & 4270c6ae8ee8bc184e0895586ef5edef & 4451,8371 & $1 a 89$ \\
\hline Tigabelas & 2e451bedc659a4970afb0e3c9f410fad & 1859,4009 & $14 b$ \\
\hline Empatbelas & $\begin{array}{c}\text { ad1ca2962c7be7738601463ac180331 } \\
\text { d }\end{array}$ & 13279,16867 & $2 b a 2$ \\
\hline Limabelas & $\begin{array}{c}\text { 7b0486e17b6256452e99e724a144448 } \\
\text { b }\end{array}$ & 5713,17233 & 2169 \\
\hline Enambelas & b63aeab57d006a0a916c12361c92b6c4 & 367,2149 & 825 \\
\hline Tujuhbelas & 4beb5c0f9797193897982916570fa445 & 1889,2603 & 92 \\
\hline Delapanbelas & 2571d496903bd67cef1ca695174a3022 & 827,6739 & $4 a 0$ \\
\hline $\begin{array}{l}\text { Sembilan } \\
\text { belas }\end{array}$ & e0e110ed1ffe640d4dbc9c5cb6ec4cbf & 743,5959 & $a 82$ \\
\hline Duapuluh & $\begin{array}{c}45 \mathrm{~d} 254 \mathrm{fd} 2 \mathrm{e} 83 \mathrm{db} 58 \mathrm{c} 3 \mathrm{~b} 8902315 \mathrm{e} 6515 \\
7\end{array}$ & 5393, 9599 & 965 \\
\hline $\begin{array}{l}\text { Duapuluh } \\
\text { satu }\end{array}$ & 869f352382abfa98ab2c07f540a65e2e & 8513,20987 & $2 c 2 b$ \\
\hline $\begin{array}{l}\text { Duapuluhdu } \\
\text { a }\end{array}$ & 108f049431bc40c3c1eee2f530726ac4 & 8273,9841 & $1 d 18$ \\
\hline $\begin{array}{l}\text { Duapuluhtig } \\
\text { a }\end{array}$ & $4 f 08 e 5 b 44 d 49 c 26 c 087 d d 4782654 f 6 f 2$ & 4117,8549 & $e 6 f$ \\
\hline $\begin{array}{l}\text { Duapuluh } \\
\text { empat }\end{array}$ & c8fb70c17723bc26ebaae5e0b3dc52eb & 47,721 & $10 f$ \\
\hline $\begin{array}{l}\text { Duapuluh } \\
\text { lima }\end{array}$ & $\begin{array}{c}\text { 35f7c674b56b1e7b387e40cd05bb162 } \\
\text { b }\end{array}$ & 1891,4399 & $e 71$ \\
\hline $\begin{array}{l}\text { Duapuluh } \\
\text { enam }\end{array}$ & $8170167029 d 09 a 0 c f e b 875 a 3610889 b c$ & 637,1739 & 616 \\
\hline $\begin{array}{l}\text { Duapuluh } \\
\text { tujuh }\end{array}$ & 7f6fc3fc79ba1a9a11c99af52bf2a022 & 8303,13957 & $238 c$ \\
\hline $\begin{array}{l}\text { Duapuluh } \\
\text { delapan }\end{array}$ & $\begin{array}{c}\text { 88e2ea7a51199b91b88dc8f08119424 } \\
7\end{array}$ & 415,3683 & $58 b$ \\
\hline Duapuluh & c475733c4391924e5bc2b4b456c7b68 & 1149,6931 & $1 a b c$ \\
\hline
\end{tabular}




\begin{tabular}{cccc}
\hline $\begin{array}{c}\text { Nama } \\
\text { Dokumen }\end{array}$ & Message Digest & $\begin{array}{c}\text { Kunci Pribadi } \\
(d, n)\end{array}$ & $\begin{array}{c}\text { Tanda } \\
\text { Tangan } \\
\text { Digital }\end{array}$ \\
\hline sembilan & 1 & & \\
Tigapuluh & 910 edae55304e1ebc8da24702499676 \\
& $\mathrm{d}$ & 771,11233 & $20 a 7$ \\
\hline
\end{tabular}

Berdasarkan hasil pengujian pada Tabel 1, dapat dilihat bahwa tanda tangan digital yang dihasilkan berbeda-beda dari setiap dokumen. Hal ini karena tanda tangan digital yang dihasilkan bergantung pada nilai message digest dan kunci pribadi yang digunakan. Selanjutnya dokumen yang telah diberi tanda tangan digital akan dikirimkan kepada penerima untuk diverifikasi menggunakan kunci publik.

Proses verifikasi dokumen elektronik menggunakan fungsi hash MD5 dan kriptografi algoritma RSA pada dokumen pertama menggunakan program yang telah dibuat dapat dilihat pada Gambar 3 berikut:

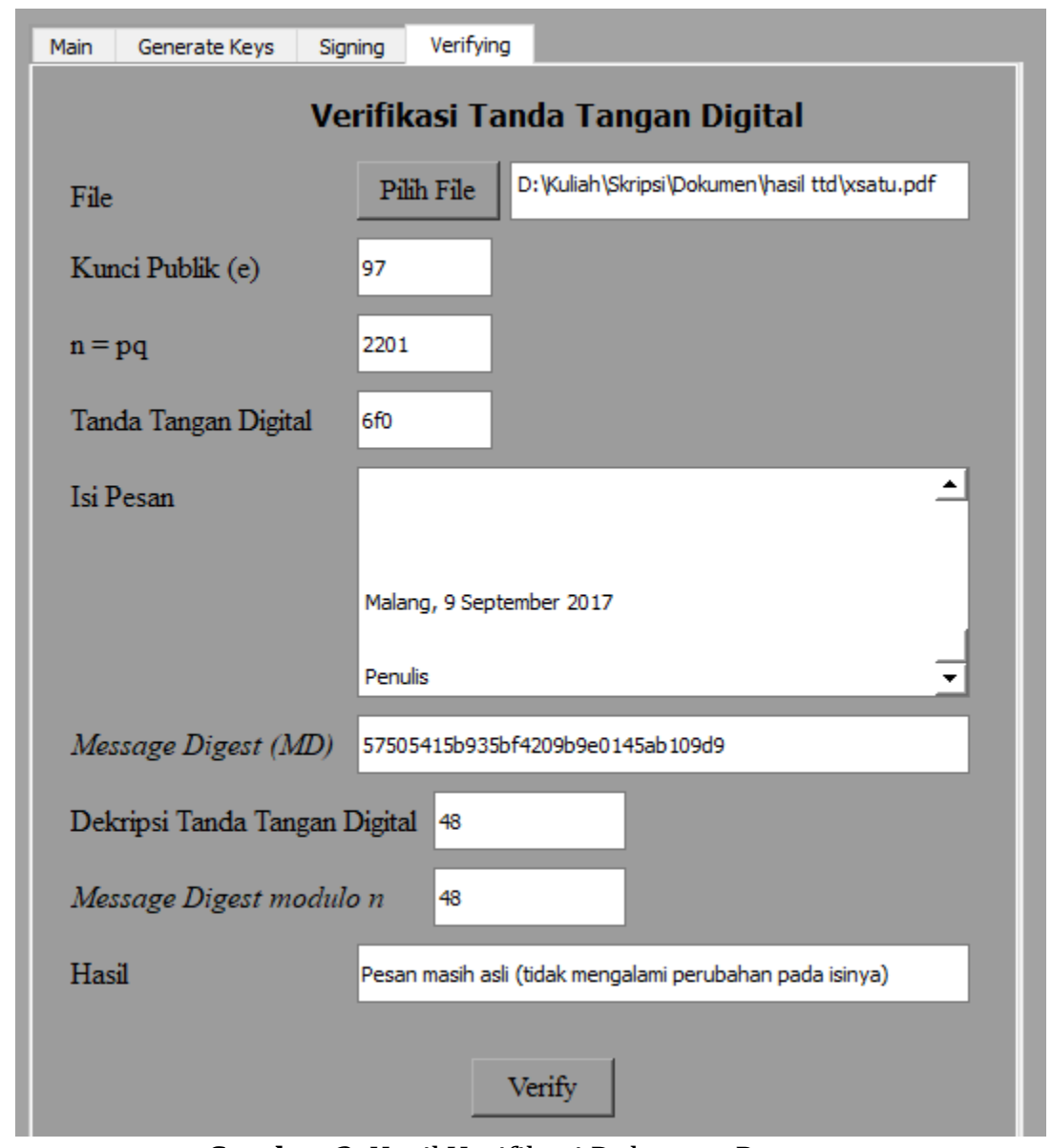

Gambar 3. Hasil Verifikasi Dokumen Pertama

Berdasarkan Gambar 3, tanda tangan digital, yaitu $6 f 0$ yang dalam desimal adalah 1776 didekripsi menggunakan kunci publik. Kunci publik yang diperoleh dari proses penandatangan dokumen pertama yang bernama satu.pdf, yaitu $e=97$. Tanda tangan digital didekripsikan dengan

$m=c^{e} \bmod n$

$=1776^{97} \bmod 2201$ 


$$
=72
$$

Hasil dekripsi yang diperoleh adalah 72 yang dalam heksadesimal adalah 48. Selanjutnya isi dokumen akan dikenakan fungsi hash, sehingga diperoleh message digest

$57505415 b 935 b f 4209 b 9 e 0145 a b 109 d 9$

Selanjutnya perhitungan message digest modulo $n$, dengan $n$ bernilai 2201 menghasilkan nilai 48. Hasil dekripsi tanda tangan digital dan message digest menghasilkan nilai yang sama, yaitu 48.

Hasil pengujian verifikasi tanda tangan digital dari tiga puluh dokumen elektronik dapat dilihat pada Tabel 2 berikut: 
Tabel 2 Hasil Verifikasi dari Tiga Puluh Dokumen Elektronik

\begin{tabular}{|c|c|c|c|c|c|}
\hline Nama Dokumen & Message Digest & $\begin{array}{l}\text { Kunci Publik } \\
(e, n)\end{array}$ & $\begin{array}{c}\text { Tanda } \\
\text { Tangan } \\
\text { Digital }\end{array}$ & $\begin{array}{c}\text { Dekripsi } \\
\text { Tanda } \\
\text { Tangan } \\
\text { Digital }\end{array}$ & $\begin{array}{c}\text { Message } \\
\text { Digest } \\
\text { modulo } n\end{array}$ \\
\hline xsatu & 57505415b935bf4209b9e0145ab109d9 & 97,2201 & $6 f 0$ & 48 & 48 \\
\hline xdua & 3a02a5a773c9596470a91bd2277dc0cd & 139,2701 & $a 77$ & 898 & 898 \\
\hline xtiga & 2004c1f59373182df37b15132a3ed255 & 113,9797 & $132 c$ & 2344 & 2344 \\
\hline xempat & $8148710 \mathrm{~b} 4171 \mathrm{f} 2206 \mathrm{~b} 579 \mathrm{c} 0 \mathrm{~b} 9 \mathrm{c} 9 \mathrm{ff0a} 2$ & 27,1837 & 122 & 299 & 299 \\
\hline xlima & 9217013676aeacd967bfa2f3a6917569 & 121,3233 & 1 ec & $35 a$ & $35 a$ \\
\hline xenam & aec44c5ba60336a61787da7e882d3461 & 133,6283 & af7 & $d 1 c$ & $d 1 c$ \\
\hline xtujuh & 00f2f16d5e31452efa09bc55e6e5ef9f & 549,3901 & $67 e$ & 459 & 44 \\
\hline xdelapan & 22ecc56816ef1677a2c8273efd077725 & 349,391 & 20 & 24 & 131 \\
\hline xsembilan & 9e3c499e9f0f3b8bf6040ee6689fb987 & 89,13561 & $266 e$ & 3093 & $2 d 86$ \\
\hline xsepuluh & dff3fe1235562e1649c6f068d6ccd2ef & 211,11581 & aae & $c 46$ & $e 40$ \\
\hline xsebelas & 6ded9e7b97014ab8af1f0dba4a90522b & 199,7807 & $31 e$ & $2 d 4$ & $6 e 7$ \\
\hline xduabelas & 90f62379b698ccb14596ea6082f98f8f & 251,8371 & $1 a 89$ & $a d a$ & 83 \\
\hline xlima & 45d05d021e65ed70f6fd773c069aac45 & 3719,4009 & $14 b$ & $7 b 1$ & $8 a d$ \\
\hline xenam & 097a161d04ff3ef878231473c862471f & 3319,16867 & $2 b a 2$ & $1 c 88$ & $3 a 7 a$ \\
\hline xlimabelas & ba9bfc4fd0ebad48ddcbbd51151f1b36 & 157,17233 & 3508 & 2445 & $b 6 a$ \\
\hline xenambelas & be40cb309db2450426963405ceb51222 & 1831,2149 & $4 b 0$ & $2 e 2$ & 700 \\
\hline xtujuhbelas & 9aae020fbf85dad179cf75415b0ee0c7 & 2321,2603 & 92 & $6 d 7$ & 319 \\
\hline xdelapanbelas & 9db4d32322c5cddecdaab9d4c0ec2236 & 435,6739 & $4 a 0$ & $11 a a$ & $104 e$ \\
\hline
\end{tabular}




\begin{tabular}{llcccc}
\hline & & \multicolumn{1}{c}{ Kunci Publik } \\
\multicolumn{1}{c}{ Nama Dokumen } & & \multicolumn{1}{c}{ Message Digest } & $\begin{array}{c}\text { Tanda } \\
\text { Tangan } \\
\text { Digital }\end{array}$ & $\begin{array}{c}\text { Dekripsi } \\
\text { Tanda } \\
\text { Tangan } \\
\text { Digital }\end{array}$ & $\begin{array}{c}\text { Message } \\
\text { Digest } \\
\text { modulo } n\end{array}$ \\
\hline xsembilanbelas & 9f48e5eb0e726dc4920c6188833842b7 & 1007,5959 & $a 82$ & 224 & 47 \\
xduapuluh & 99f6500771b08bdd2c004230cce5cb98 & 257,9599 & 965 & $1 b 10$ & $d d 1$ \\
xduapuluhsatu & 6b231e65a3a1157ad55e75b74fe806d6 & 617,20987 & $2 c 2 b$ & 913 & 4933 \\
xduapuluhdua & 391ee7b8c53da3f476c7985857568ae7 & 545,9841 & 1710 & 269 & $8 b 9$ \\
xduapuluhtiga & 6b70afa9c5e09ebc145a5518b8d08f55 & 193,8549 & 1807 & 1543 & 1505 \\
xduapuluhempat & 17c9d5d9199a66bedb1c13cbc650a94a & 599,721 & 217 & $24 a$ & 255 \\
xduapuluhlima & 2ec83a6d69ce5de13af3dc6da3bf6305 & 115,4399 & $e 71$ & $26 c$ & $96 c$ \\
xduapuluhenam & b02c772c99017d26260764b2af63d523 & 13,1739 & 616 & $3 c 5$ & 652 \\
xduapuluhtujuh & 2daca0119af6f4c557091bbda0228eaf & 207,13957 & $238 c$ & 2768 & $e f$ \\
xduapuluhdelapan & 231b433ee003b7a4b716f56222b2b6e7 & 3511,3683 & $58 b$ & $d f a$ & $8 e 7$ \\
xduapuluhsembilan & 78f46ee71357f021deb7df0d7360f302 & 29,6931 & $1 a b c$ & $9 b e$ & $119 c$ \\
xtigapuluh & 820c6681994fd814d790d7e9cad00059 & 71,11233 & $20 a 7$ & $1 b 2 a$ & $b 10$ \\
\hline
\end{tabular}


Berdasarkan hasil pengujian pada Tabel 2, dapat dilihat bahwa dokumen pertama sampai dokumen keenam menghasilkan nilai dekripsi tanda tangan digital dan message digest modulo $n$ yang sama, sedangkan pada dokumen ketujuh sampai dokumen ketiga puluh menghasilkan nilai dekripsi tanda tangan digital dan message digest modulo $n$ yang tidak sama. Hal ini karena dokumen ketujuh sampai ketiga puluh telah mengalami perubahan pada isinya, yaitu berupa perubahan, penambahan, pengurangan, dan pembalikan kata ataupun angka.

\section{KESIMPULAN}

Setiap dokumen elektronik menghasilkan tanda tangan digital yang berbeda-beda satu sama lain. Hal ini karena tanda tangan digital yang dihasilkan sangat bergantung pada nilai message digest yang diperoleh dari isi pesan dan kunci pribadi yang digunakan pengirim untuk mengenkripsi message digest. Dokumen elektronik yang tidak mengalami perubahan pada isinya menghasilkan nilai dekripsi tanda tangan digital dan message digest modulo $n$ bernilai sama. Sedangkan dokumen elektronik yang telah mengalami perubahan pada isinya menghasilkan nilai dekripsi dan message digest modulo $n$ bernilai tidak sama. Hal ini menunjukkan bahwa segala bentuk perubahan pada isi dokumen akan merubah nilai message digest.

\section{DAFTAR PUSTAKA}

[1] Suspahariati dan R. Susilawati, "Penerapan Sistem WFH (Work From Home) dan Dampaknya terhadap Kinerja Staf dan Dosen Unipdu Jombang selama Pandemi Covid-19," Jurnal Manajemen dan Pendidikan Islam, vol. VI, no. 2, pp. 229-240, 2020.

[2] T. Yuniati dan M. F. Sidiq, "Literature Review: Legalisasi Dokumen Elektronik Menggunakan Tanda Tangan Digital sebagai Alternatif Pengesahan Dokumen di Masa Pandemi," Jurnal RESTI (Rekayasa Sistem dan Teknologi Informasi), vol. IV, no. 6, pp. 1058-1059, 2020.

[3] M. Benedict, M. A. Budiman dan D. Rachmawati, "Perbandingan Algoritma Message Digest 5 (MD5) Dan GOST Pada Hashing File Dokumen," Jurnal Teknik Informatika Kaputama (JTIK), vol. I, no. 1, pp. 50-61, 2017.

[4] K. Somsuk dan M. Thakong, "Authentication System for E-certificate by Using RSA's Digital Signature," TELKOMNIKA (Telecommunication Computing Electronics and Control), vol. XVIII, no. 6, pp. 29482955, 2020.

[5] M. A. Nazal, R. Pulungan dan M. Riasetiawan, "Data Integrity and Security using Keccak and Digital Signature Algorithm (DSA)," IJCCS (Indonesian Journal of Computing and Cybernetics Systems), vol. XIII, no. 3, pp. 273-282, 2019.

[6] E. Army, Bukti Elektronik dalam Praktik Peradilan, Jakarta: Sinar Grafika, 2020.

[7] I. P. A. Swastika dan I. G. L. A. R. Putra, Audit Sistem Informasi dan Tata Kelola Teknologi Informasi, Yogyakarta: CV ANDI OFFSET, 2016.

[8] D. Ariyus, Pengantar Ilmu Kriptografi: Teori Analisis dan Implementasi, Yogyakarta: CV ANDI OFFSET, 2008.

[9] R. A. Azdy, “Tanda tangan Digital Menggunakan Algoritme Keccak dan RSA," Jurnal Nasional Teknik Elektro dan Teknologi Informasi (JNTETI), vol. V, no. 3, pp. 184-191, 2016.

[10] Y. Anshori, A. Y. E. Dodu dan D. M. P. Wedanata, "Implementasi Algoritma Kriptografi Rivest Shamir Adleman (RSA) pada Tanda Tangan Digital," Techno.Com, vol. XVIII, no. 2, pp. 110-121, 2019.

[11] E. C. Prabowo dan I. Afrianto, "Penerapan Digital Signature Dan Kriptografi Pada Otentikasi Sertifikat Tanah Digital," Komputa : Jurnal Ilmiah Komputer dan Informatika, vol. II, no. 6, pp. 83-90, 2017.

[12] R. Munir, Kriptografi, Bandung: Informatika, 2019.

[13] Sumarno, I. Gunawan, H. S. Tambunan dan E. Irawan, “Analisis Kinerja Kombinasi Algoritma MessageDigest Algortihm 5 (MD5), Rivest Shamir Adleman (RSA ) dan Rivest Cipher 4 (RC4) Pada Keamanan 
E-Dokumen," Jurnal Sistem Informasi dan Ilmu Komputer Prima (JUSIKOM PRIMA), vol. II, no. 1, pp. 4148, 2018.

[14] R. H. Sianipar, Java untuk Kriptografi, Yogyakarta: Penerbit Andi, 2017.

[15] Pahrizal dan D. Pratama, "Implementasi Algoritma Rsa Untuk Pengamanan Data Berbentuk Teks," Pseudocode, vol. III, no. 1, pp. 44-49, 2016.

[16] R. M. McLeod, K. Ranson dan L. Biehl, The generalized Riemann integral, JSTOR, 1980.

[17] C. Godsil dan G. F. Royle, Algebraic graph theory, vol. 207, Springer Science \\& Business Media, 2013.

[18] A. Gara, M. A. Blumrich, D. Chen, G.-T. Chiu, P. Coteus, M. E. Giampapa, R. A. Haring, P. Heidelberger, D. Hoenicke, G. V. Kopcsay dan others, "Overview of the Blue Gene/L system architecture," IBM Journal of Research and Development, vol. 49, no. 2, pp. 195-212, 2005.

[19] J. France, J. H. Thornley dan others, Mathematical models in agriculture., Butterworths, 1984.

[20] F. E. Browder, "Nonexpansive nonlinear operators in a Banach space," Proceedings of the National Academy of Sciences, vol. 54, no. 4, pp. 1041-1044, 1965.

[21] M. J. Berger dan J. Oliger, "Adaptive mesh refinement for hyperbolic partial differential equations," Journal of computational Physics, vol. 53, no. 3, pp. 484-512, 1984.

[22] R. H. Sianipar, Java untuk Kriptografi, Yogyakarta: Penerbit ANDI, 2017. 